\title{
MANAGEMENT PRINCIPLES OF TECHNOPARKS IN TRANSITIVE COUNTRIES UNDER CONDITIONS OF GLOBALIZATION
}

\begin{abstract}
The aim of work was to investigate the shapes of the innovative environment of the past and the new ones of post-industrial information society, the specificity of technology parks has been allocated. Analysis of the practice of creating industrial parks in the United States, Europe, Israel, Russia and Ukraine showed differences in approaches in the West and former Soviet Union. In the former case, they create a fundamentally new model of innovative processes management, reflecting the specifics of new social system, in the latter there is an attempt to modernize and adapt the old form to new tasks, which increases the gap in science and technology as well as the economic dependence of the post-Soviet countries. Globalization provides both a challenge and new opportunities for the development of countries as well as the global market. Creating technology parks can help transition countries emerge from the crisis and compete on an equal footing with the leading world economy players. Technology parks can collaborate with other types of innovative environment: university laboratories, research institutes, research and production complexes. They can be included as structural subsystems into larger scientific-industrial associations, preserving their own characteristics and autonomy. The proposed theoretical concept of controlling technology parks is adequate to cultural patterns, resource and development needs of the country, finishing their transition to the information society. It may get businesspersons, researchers and political circles interested. Obviously, this model needs to be tested in practice. In case of successful approbation in Ukraine, it may be implied in the innovative environment of other transition countries.
\end{abstract}

Keywords: technoparks, innovation, innovation environment, model of management, globalization

\section{INTRODUCTION}

The most important need of transitive countries is finalization of systematic transformation with the help of innovations to provide further stable development and competition with leading players in the world economy. Under the conditions of globalization, countries that organized effective innovative environment in various forms become leaders. Due to scientific and technology parks, new ideas are realized faster which will boost economy, enhance the quality of life and development of the region. Creation of technology parks in post-Soviet countries slows down because there is no awareness of the essence of new innovational environment and the principles of management of changing process as well as conditions for their application are absent. .

\footnotetext{
${ }^{1}$ Luibov Chernova, PhD, Department of Philosophy and Politology of Prydniprovska State Academy of Civil Engineering and Architecture, Dnepropetrovsk, Ukraine, e-mail: chernlub@ukr.net
} 


\section{MANAGEMENT PRINCIPLES OF TECHNOPARKS UNDER CONDITIONS OF GLOBALIZATION}

Problem statement. The meaning of such innovational form as technoparks in the post-Soviet countries is poorly studied. Frequently, during the implementation of technoparks, in post-Soviet countries, their authors are trying to breathe new life into old constructions without understanding the fact that management principles and functioning of these organizations are based on different fundamentals.

Research tasks: 1 . Analysis of laws peculiarities and national specificity of changes brought into social and innovational environment during the transition to information society.2. Comparative analysis principles of scientific organization management in industrial and post-industrial society. 3. Elaboration of conceptual management model for technoparks as a new type of innovational environment organization adequate for transitive post-Soviet countries. 4. Demonstration of perspectives of technology parks as strategic task for catch-up growth countries.

Research results. In_postindustrial society there is a registered increase in the number and the role of highly skilled specialists in the sphere of IT and science ${ }^{2}$ Science, knowledge and education become leading branches of production. Innovations become main and the most precious products. ${ }^{3}$ International scientific collaboration is developing (projects such as «Collider», «EU FutureICT», «Living Earth Simulator» and others). Social space turns from the space of places to the space of flows ${ }^{4}$.Globalization, international Funds and projects lead to the fact that innovations are produced in various places/countries jointly, they are funded from joint sources and the production base is usually located in the third countries, mostly in "transitive" ones .Integration of professions and sciences, spheres of society life takes place. The world becomes more open and global.

National models of informational society are distinguished by the combination of 4 components determining further development of the country and competitiveness at the world stage:

1) various forms of innovational environment;

2) investment and financing sources;

3) production base;

4) government policy in the sphere of innovations.

According to the experience of 38 world countries, M.Castels singled out eight transformation models of industrial societies ${ }^{5}$

$1^{\text {st }}$ model is «Innovational environment», that includes science, capital, variety of small businesses, highly efficient professionals (Silicon Valley and technoparks in the USA) creating a self-developing.

$2^{\text {nd }}$ model is «Transnational corporation»(TNC), engaged in own developments. Drawback - corporate isolationism, monopoly of discovery, invention for business purposes.

\footnotetext{
2 D Bell, The coming of Post-Industrial society, Heinemann Educational, London 1974, http://www.polybiblio.com/lameduck/688.Html.

${ }^{3}$ M. Castells, An Introduction of the Information Age, "City" 1997/7. p. 6-16.

${ }^{4}$ M. Castells, The Rise of Network Society, Vol.1: Of the Information Age: Economy, Society and Culture, Blackwell, Oxford 1996, p. 256.

${ }^{5}$ Ibidem, p. 187-195.
} 
$3^{\text {rd }}$ model is "Governmental support" of technological innovation through private companies, budgeted by the government and receiving orders for researches that lead to enhancement of foreign technology (many post-Soviet countries).

$4^{\text {th }}$ model is "Collaboration of the government with private companies" is similar to the $3^{\text {rd }}$ model, though functions only in open market conditions, including through international groups of scientists. For example, France and the UK develop so.

$5^{\text {th }}$ model is "Governmental protectionism", where the country is trying to elaborate new technology from scratch. Examples are India and China.

$6^{\text {th }}$ model is "Desire of military superiority" initiates independent development of new technology; however, the principle of free information exchange in the modern society is not compatible with the requirements of military confidentiality. That is why, lagging behind is unavoidable in the long term perspective, as it actually happened in the USSR.

$7^{\text {th }}$. "Interstate cooperation with private investment" - European community, where cooperation is fulfilled at the government level as well as at the level of private companies in the scale of whole Europe and in the national framework.

$8^{\text {th }}$. "Diffusion of Innovations", with the basic principle of implementation of already available foreign modern technology in own country. The main task of the given model is elaboration of already available foreign modern technology to given conditions. This type of development is characteristic of Ukraine, however, there exist features of other models.

Let us analyze the first component which is innovation environment and its organizational models.

To ensure appearance of innovational product, it is necessary to create environment for their production that would integrate activity of specialists in various fields, level of knowledge and scientific experience and would perform synthesizing functions, namely: innovational, economical, production, educational, implementing and other. ${ }^{6}$ We consider technoparks to be such environment.

Technopark can be defined as optimally organized scientific and industrial zone where collaboration, exchange of ideas and information between enterprises and scientific organizations is performed with the aim to introduce innovations ${ }^{7}$ Such definition unreasonably combines all possible forms of innovational scientific organizations originating in previous epochs and new ones, being at the stage of their spring.

Having analyzed basic forms of organization of inventive activity, five types of innovational environment organization can be singled out.

University laboratories. Their advantage is a combination of science and education, involvement of students in scientific research, which enhances the quality of knowledge, unites theory and practice, increases motivation in learning and scientific work. Selection of research topics is made by Scientific Councils of universities who also control expenditures and research results. Should the topic of research is inadequate to the formed specialization, the scientists can try to find financing by themselves and use the laboratories of higher educational establishments on contractual basis. The course of research is discussed on weekly seminars; results are published in the open scientific press.

\footnotetext{
${ }^{6}$ A. Gore, Basic Principles for Building an Information Society, "International Information Communication and Education" 1996/2, p. 226-228.

${ }^{7}$ L. Kompanzheva, Contsept in formatsion novogo obschestva kak cognitivnaya osnova izmenenuya yazukovoj kartinu mira sovremenogo obschestva, "Naykovy zapiski. Vypysk" 89/1 (2010), p. 250-254.
} 
Author's rights are shared between the groups of researches and universities or private sponsors on the contractual basis. The requirements to intellectual property rules for a wide access to information have been alleviated. This experience should undoubtedly be applied, but university should not be identified with technoparks, although there is similarity between them. The main task of universities is education, and research work is a means and the source of additional incomewhereas the aim of technopark is "raising" innovational projects and ideas.

Classical academic science and core scientific and research institutes (SRI) emerged in the form of national academies of sciences with state protectorate or directly at royal court. They were engaged in fundamental research. Later, specialized SRI emerged (mainly in socialistic countries). They were engaged in applied problems by "state order" or the order of enterprises (economical order). Advantage: concentration of resources and efforts in one spot/enterprise, specialization of topic, strict control of the management all turned into an obstacle with time.

Narrow specialization and bureaucratization of making solution, dependence on customers, outdated resource base, poor financing, "brain drain", isolation from production all that turned given form of science organization vulnerable at post-Soviet space. Only SRIs - participants of international projects are still afloat, alongside with institutes of defense designation or scientific centers supported by business. In the latter case, results of scientific research and rights to them belong to the customer and are "commercial secret" which acquired the name "feudalism of knowledge" [7]. ${ }^{8}$ In this case they gradually pass into a different form.

Scientific production complex (SPC)/ or program (SPP) and scientific centers of industrial corporations. Peculiarities: vast territories and large staff including several administrative and territorial units or large international projects. Advantage: integration of science and production. Several major scientific and production centers, participating in the research, had related or common interdisciplinary theme under the auspices of the government ("Skolkovo" in Russia) or business (TNK). In Ukraine today six similar stateowned SPP are under implementation in the field of power engineering, metallurgy, atomic power engineering, space explorations, ship- and aircraft building and other. ${ }^{9}$

Regional scientific center has complex branched infrastructure and management system, large scale of project realization. The majority of results and the process itself are highly classified. SPC may include technology towns or scientific and technical parks, industrial enterprises-giants, scientific centers and SRI are dispersed. That leads to the notion of "technopark-plant" occurring in the literature, however, this type of innovational environment can hardly be called a technopark. It differs in tasks, level of scientific search, management types and privacy of research results.

Venture companies appeared as a response to the necessity to approximate inventors to the potential consumer in the conditions of free competition. Venture company proposes the interconnection of the following components: innovation at the improvement stage; economical and legal aid to scientists to carry the idea to an industrial sample or patent; presence of public demand for the implementation of the given ideas and/or entrepreneur

\footnotetext{
${ }^{8}$ W.T. Waller, Ceremonial Encapsulation and Corporative Culture Hegemony, "Journal Economic Issues" 1987/21, p. 121-128.

9 T.M. Chipko, Technoparks in Ukraine, http://www.geograf.com.ua/geoinfocentre/20-human-geographyukraine-world/759-tekhnoparki-ukrajini.
} 
ready to base business on it; investor with a spare capital. Venture financing is implemented through either incorporation or crediting. It is rather a form of capital investment in the scientific sphere with an increased level of risk, than an innovational environment itself. The company receives author's rights for the perspective yet unchecked idea (risk factor) and offers other companies a participation in financing. All rights, implementation process, and, eventually, profit is all that the company and its investors undertake. Venture companies carry the idea to implementation or to a patent within a short period of time which is similar to technopark task, but they pursue strictly commercial aims and differ with organizational principles of management.

Analyzed forms of innovational environment emerged in the industrial society. Technoparks emerged during the transition to the information society and are a new type of open innovational environment adequate to new social conditions. The main goal of scientific technoparks is growth of a local community by the means of promotion of innovation culture, increasing competition of innovation business and scientific organizations. To achieve these goals, technopark stimulates and manages the flows of knowledge and technology between universities, scientific-research institutes, companies and market ${ }^{10}$.

In scientific literature the following notions are usually confused: "technopark plant", "technopark - university", "technopark - SRI", "technopark - target scientific program". They are rather hybrid forms of combination of previous types of innovational environment and a new type. Mechanical attempt to re-build old forms into new ones only leads to the change of the signboard without changing the principles of scientific activity organization and ways of spreading new knowledge.

The prototypes of a technopark are the most successful innovational companies of the present, namely: Google, Apple, Facebook that started as groups of friends, working within the circle of their interests, mutually adding the potential and contribution of participants [5]. Importantly, the closest creative relations in these groups are supported by specially created social environment, partnership of the Customer and scientists, freedom of creativity that provides fruitful invention activity.

Generally, technoparks are "garden/incubator of ideas". Technopark is a system of a new type of innovation, open for visitors, students, tourists and businesspeople. Organizational and management principles combined in themselves the features of "informational society"and"society of knowledge", namely: fair competition of ideas; equal start possibilities for mature, little-known and novice scientists; for separate scientists and groups, free spread of new knowledge.

Having analyzed scientific literature and international practical experience of technoparks establishment, it can be concluded that the notion of "technological park" is used as a metaphor for a certain concept of "garden"/“incubator". We can offer the following operative working notion: technopark is an innovational environment where socially significant innovations ready for implementation are "raised" for the sake of the whole society.

A combination of words "techno" and "park" is a matter of principle. Park is a place where something new grows should there be appropriate conditions. During the Contest, projects and groups of researchers are selected on the basis of topical need of the region and, like a gardener, create conditions for productive invention activity. The same people

\footnotetext{
10 Ponyatie, funkzhii i zadachi of technoparkov// Expert RA /2015-http://www.raexpert.ru/ researches/technopark/part1.
} 
work at a project during a certain period. The result is an experimental model, technology or service - any new product that can be sold, presented or implemented in production, learning, management, life and leisure. Like harvest in gardens, themes of research and people who do it create stimuli for innovational process fruitfulness. Continuous creation of a new science-intensive product is a basic function of a technopark.

Technopark is a peculiar "incubator" that not only produces innovations (technologies), ready for implementation spread, but also for new names of inventors. Temporary research teams are gathered for the particular project that provides input of fresh forces and ideas. It makes principle distinctive feature of technoparks from other scientific structures and this is what makes success.Basic principles of technopark management:

- Different profiles of research topics;

- Competition of topics and research teams on the basis of social needs and expertise;

- Freedom of creativity during project implementation;

- Interchangeability of research groups and projects at the same site;

- $\quad$ Mixed financing principle;

- $\quad$ Public control of the project progress, expenditures and implementation;

- $\quad$ Fast and open access to the results of investigation after sealing author's rights. This model "considers many strategies for community sustainable development [...] It ranges from the soft infrastructure of policy, finance, economic development and education to the specific technical, recruitment, and management considerations in industrial park design"11.

Technopark management and fundraising for separate projects and general costs on the project is fulfilled by external managing company (Board or Management). A contract with specific conditions is signed with every research team. Technopark Board includes the most authoritative scientists, patrons, sponsors, managers, lawyers and financers. They also control condition of compliance with contracts and expenditures.

Technopark projects are financed from various sources: state, sponsors, investors of certain projects, own money earned, interest contribution from author's dividends of "graduates".

Author's rights are distributed according to shared principle: major part to the author(s) of the elaboration, a certain share to the technopark for financing new projects and, if provided by the Contract, a certain share to the investor. However, more often investors buy already tested product or technology, "fruit" of technopark. Additional source of technopark financing is the income from exhibitions, seminars, learning centers being an obligatory element of any technopark as well as profits from implementation of new scientific ideas (25-30\% of profit as a rule). Besides that, part of the technopark income is due to tourism. That is why, alongside with a scientific zone (laboratories), exhibition and learning pavilions, modules of technoparks are complexes with landscape-park architecture, historical and art-objects attractive to tourists. They are simultaneously shown scientific laboratories and open access workshop. They are told of previously realized and current scientific projects which encourages spread of information regarding innovations

\footnotetext{
11 Eco-Industrial Parks: A Handbook for Local Development Teams, RPP International 1998, http://gei.ucsc.edu/eco-industrial_parks.html.
} 
and the technopark in the society. This is the main difference of a technopark from commercial and state-owned innovational organizations.

Such model gives possibility not only to receive additional income but also attracts businesspeople to innovational activity. A region that creates technoparks at its territory achieves accelerated development of economy, scientific-production and social structures, attraction of highly qualified professionals, job places, investors and tourists. Technoparks create a social innovational environment of an absolutely new self-developing type. It becomes the main factor of further stable scientific-technological, economic and social developmentof society.

The authors propose the following principles a conceptual basis of technopark functioning and development for transitive countries:

- Compactness-daily functional working cycle of small-scale specialized groups is held at objects situated at a distance of 15-minute walk; zones for visitors and guests may occupy territories of 1-2 hours of walk.

- Specialization and confines - technopark territory has got a distinct differentiation: common spaces with open access for everyone; specialized zones for work and study; zones of restricted access, "behind glass" in order to protect author's rights.

- Cluster localization - group of associated territories and people on the basis of specialized functions: inventors, managers, guides, attendants, visitors.

- Matrix organizational structure - cluster localization leads to formation of specialized elements, whose combined groups create basic modules (technopark matrix). The entire functional cycle of a technopark is organized with the help of modules, although modules can be internally transformed and recombined for new targets and tasks.

- Openness, transparency, accessibility -ensure common spaces. Well-organized, open parks are established around functional groups. Exhibition pavilions, conference and seminar halls, common places of rest and communication

- Bright integral image forming a unique "spirit of the place" (a brand) with which technopark and its products will be associated, leaving "memories" from visitors.

- Accessibility of research results reduces time for idea promotion to implementation, fighting the barriers of "feudalism of knowledge" and "commercial secret" and is achieved through educational and exhibition modules of the technopark and tourist excursions. Extensive public control as well as PR-informing about new technologies and products - perform educational and implementation function.

- Equal possibilities in approbation of ideas and technologies for already known scientists and beginners (social fairness) are executed through open contests organized by the Management Board of the technopark.

- Diversification of sources of financing and research theme decreases the risk of failures and ensures supply of resources for further development of a technopark.

\section{CONCLUSIONS}

1. Technoparks are a basic element of informational society and a stimulus for the execution of a creative potential of the country. Establishment of small and medium organizations dealing with elaboration of science-intensive produce in the form of technoparks will help transitive countries recover from the crisis and be competitive in the world arena. 
2. Researches, conducted in technoparks, refer to application layer of science. They possess a wide base for implementation and spread. Technopark is a multifunctional system of organization and spreading innovations based on new principles.

3. Despite all diversity of technoparks, there are two fundamental universal features of their practical models: uniqueness and dynamism.

4. Uniqueness is expressed by unique projects and an internal complex of a technopark for various territories, countries, cultures. This peculiarity does not exclude basic principles of technoparks management.

5. The second feature is dynamism which is expressed in flexibility of changes in the organization of technopark activity as a response to changes in needs and conditions. This peculiarity ensures the development of technoparks in time and change management as a system, ready for quick internal structural transformations. Thus, a technopark is a flexible and mobile system of production and spreading of innovations, operatively reacting to new requirements of business, education, state and society, which, in its turn, conditions its further development.

6. Technoparks function as autonomic systems collaborating with other types of innovational environment: universities, SRI, SPC, TNK, international scientific centers and Funds. Technoparks can be part of bigger structures as a substructure, however, in this case they should preserve features of a technopark, or else they will lose their essence.

\section{REFERENCES}

[1] Bell D., The coming of Post-Industrial society, Heinemann Educational, London 1974, http://www.polybiblio.com/lameduck/688.Html.

[2] Castells M., An Introduction of the Information Age, "City" 1997/7, p. 6-16.

[3] Castells M., The Rise of Network Society, Vol. 1: Of the Information Age: Economy, Society and Culture, Blackwell, Oxford 1996.

[4] Chipko T.M., Technoparks in Ukraine, http://www.geograf.com.ua/geoinfocentre /20-humangeography-ukraine-world/759-tekhnoparki-ukrajini.

[5] Eco-Industrial Parks: A Handbook for Local Development Teams, RPP International 1998, http://gei.ucsc.edu/eco-industrial_parks.html.

[6] Europe and Central Asia Regional Conference on Industrial Parks, 17-18 April 2012, Baku, Azerbaijan, https://www.unido.org/fileadmin/user_media/UNIDO_Worldwide/Europe_ and_NIS_Programme.

[7] Kompanzheva L., Contsept informationogo obschestva kak cognitivnaya osnovai zmenenuy yazukovoj kartinu mira sovremenogo obschestva, "Naykovy zapiski. Vypysk" 89/1 (2010), p. 250-254.

[8] Festel G., Würmseher M., Challenges and strategies for chemical/industrial parks in Europe, "Journal of Business Chemistry" 2013/06, http://www.businesschemistry. org/article/ ?article $=173$.

[9] May Ch., The Information Society: A Sceptual view, Polity Press, USA 2000.

[10] Gore A., Basic Principles for Building an Information Society, "International Information Communication and Education" 1996/2, p. 226-228.

[11] Ponyatie, funkzhii I zadachi of technoparkov, "Expert RA" 2015, http://www.raexpert.ru/ researches/technopark/part1.

[12] Technoparki stran mira: organizazhiya deyatelnosti I sravnenie, ed. V.A. Barinovoy, "Delo" RANXiGS 2012.

[13] Waller W.T., Ceremonial Encapsulation and Corporative Culture Hegemony, "Journal Economic Issues" 1987/21, p. 121-128. 


\section{ZASADY ZARZĄDZANIA PARKAMI TECHNOLOGICZNYMI W KRAJACH TRANSFORMUJĄCYCH SIĘ W WARUNKACH GLOBALIZACJI}

Celem artykułu jest badanie form innowacyjnego środowiska w przeszłości i w nowych warunkach postindustrialnego społeczeństwa informacyjnego, ze szczególnym uwzględnieniem specyfiki parków technologicznych. W analizie praktyki tworzenia parków technologicznych w Stanach Zjednoczonych, Europie, Izraelu, Rosji i na Ukrainie pokazano różnice w podejściach na Zachodzie i w państwach należących do byłego Związku Radzieckiego. W pierwszym wypadku tworzony jest zupełnie nowy model zarządzania procesami innowacyjnymi, obrazujący specyfikę nowego systemu społecznego; w drugim - podejmuje się próbę modernizacji i adaptacji starych form do nowych zadań, co zwiększa opóźnienie w dziedzinie naukowo-technicznej i ekonomiczną zależność krajów poradzieckich.

Globalizacja jest jednocześnie wyzwaniem i szansą dla rozwoju kraju i dla rynku światowego. Tworzenie parków technologicznych może pomóc krajom przechodzącym transformację wyjść z kryzysu i konkurować na równi z czołowymi graczami światowej gospodarki. Parki technologiczne mogą współpracować z innymi typami innowacyjnego środowiska: laboratoriami uniwersyteckimi, instytutami naukowymi, kompleksami naukowoprzemysłowymi. Jako strukturalne podsystemy mogą wchodzić w większe naukowowytwórcze ugrupowania, zachowując swoją indywidualność i autonomię. Proponowana teoretyczna koncepcja zarządzania parkami technologicznymi odpowiada kulturowym wzorcom, zasobom i potrzebom rozwoju państw w końcowym stadium przejścia do społeczeństwa informacyjnego. Koncepcja ta może wzbudzić zainteresowanie w środowiskach biznesmenów, naukowców i polityków. Z pewnością model wymaga weryfikacji w praktyce. W wypadku jej udanej akceptacji na Ukrainie może być wdrażana w innowacyjnym środowisku innych krajów transformujących się.

Słowa kluczowe: parki technologiczne, innowacje, środowisko innowacyjne, model zarządzania, globalizacja

DOI: 10.7862/rz.2015.mmr.3

Tekst złożono w redakcji: marzec 2015

Przyjęto do druku: marzec 2015 